\title{
ICE PATCH HUNTING IN THE GREATER YELLOWSTONE AREA, ROCKY MOUNTAINS, USA: WOOD SHAFTS, CHIPPED STONE PROJECTILE POINTS, AND BIGHORN SHEEP (OVIS CANADENSIS)
}

\author{
Craig M. Lee and Kathryn Puseman
}

\begin{abstract}
Ice patches and the alpine are important elements of the sociocultural landscape of the Greater Yellowstone Area, and they transcend the jurisdictional boundaries that divide the lands on which they occur. The ice patch record complements traditional sources of archaeological knowledge through the addition of well-dated organic artifacts, such as shafts from hunting tools, recovered in a readily recognizable context. This paper examines the types of wood used in the manufacture of hunting implements recovered at Greater Yellowstone Area ice patches through the analysis of nine unique wooden shafts and shaft fragments from five sites. Five shafts are birch (Betula spp.), two are willow (Salix spp.), one is fir (Abies sp.), and one is pine (Pinus sp.). The shafts included in this analysis range in age from $9230 \pm 25$ B.P. to $215 \pm 20$ B.P. Diagnostic Oxbow and Pelican Lake chipped stone projectile points recovered in association with ice patches provide additional temporal resolution regarding use of these features. One of the four sites that yielded wooden shafts contains a record of bighorn sheep (Ovis canadensis) hunting between $3885 \pm 25$ B.P. and $879 \pm 23$ B.P.
\end{abstract}

Las zonas de hielo y de alta elevación son elementos importantes del paisaje sociocultural del entorno de Yellowstone, en el noroeste de Wyoming, Estados Unidos, y trascienden los límites jurídicos de las tierras en las que ocurren. El registro de las zonas de hielo complementa las fuentes tradicionales de conocimientos arqueológicos gracias a la adición de artefactos orgánicos bien fechados, como por ejemplo los mangos de herramientas de caza recuperados de un contexto inmediatamente reconocible. Este trabajo examina los tipos de madera utilizados en la fabricación de herramientas de caza recuperadas en la región alrededor de Yellowstone por medio del análisis de nueve mangos de madera completos o fragmentados provenientes de cinco sitios. Cinco de los mangos encontrados están hechos de abedul (Betula spp.), dos son de sauce (Salix spp.), uno es de picea o conífero (Abies sp.), y el otro es de pino (Pinus sp.). Los mangos incluidos en éste análisis fluctúan en edad entre 923025 a.P. y 21520 a.P. Fragmentos diagnósticos de puntas líticas Oxbow y Pelican Lake asociados a los glaciares dan una idea más completa del periodo cuando estos lugares fueron ocupados. Uno de los cuatro sitios donde se recuperaron estas puntas de herramientas de madera contiene evidencia de caza de borrego cimarrón (Ovis canadensis) entre 3885 a.P. y 87923 a.P.

$\mathrm{M}$ elting ice patches are revealing an incredibly unique array of ancient plant and animal remains as well as archaeological materials that are shedding new light on past climate variability in highelevation environments and Native American use of these landscapes. These discoveries-the ice patch record-are nothing short of astonishing, scientifically important, and at risk of loss as glaciers and perennial ice patches melt across western North America (Fountain 2009). The archaeological record associated with ice patches is not impacted by the same formation processes that affect most sites, and, consequently, they can contain the usually invisible organic component of hunting systems.

Rocky Mountain and Northern Plains hunting technologies are primarily known from-or at least academically discussed using-lithic projectile points because of their prevalence in

Craig M. Lee University of Colorado, Institute of Arctic and Alpine Research (INSTAAR), Montana State University, Department of Sociology and Anthropology and Metcalf Archaeological Consultants, Campus Box 450, Boulder, CO 80309, USA (craig.lee@ colorado.edu)

Kathryn Puseman $\square$ Paleoscapes Archaeobotanical Services Team (PAST), 734 Mockingbird Trail, Bailey, CO 80421, USA (paleoscapes@gmail.com) 
the archaeological record. Far less is known about the wooden elements comprising the dart and arrow foreshafts and shafts that accompanied the lithic technology. Ice patches preserve these elements in the systemic context in which they functioned as hunting implements. They can preserve complete examples of tools (Lee 2010) and complement the recovery of similar materials in cave and rock shelter sites that are often broken and discarded shafts or shafts undergoing manufacture, modification, or refurbishment (e.g., Gruhn 1961; Husted and Edgar 2002; Weathermon 2011).

Complete dart and arrow foreshafts and shafts recovered at melting ice patches in Alaska, the Yukon Territory, and the Northwest Territories illustrate the care that went into the delivery of a projectile to its target (e.g., Alix et al. 2012; Andrews et al. 2012; Dixon et al. 2005; Hare et al. 2012). Elements affixed to these tools include carefully applied coloring (Dixon et al. 2005; Dixon et al. 2007), adhesive resin (e.g., spruce [Picea spp.]) mixed with ochre (Helwig et al. 2008; Helwig et al. 2014), and non-game bird fletching from raptors such as eagles (Dove et al. 2005). The organic elements illustrate the entwined concepts of reliability and maintainability (e.g., Bamforth and Bleed 1997; Bleed 1986). From a mechanical perspective, while any feather with the requisite stiffness could function as fletching, the selection of raptor feathers augurs for reliability as a criterion, whereas the occurrence of foreshafts reflects toolkit maintainability as a hedge against loss.

Over the last decade, research has identified wooden shafts and faunal remains at melting ice patches in the Greater Yellowstone Area (GYA) (northern Rocky Mountains) of Wyoming and Montana. The GYA is comprised of contiguous high-elevation lands and intervening valleys managed by the Custer-Gallatin National Forest, Shoshone National Forest, BridgerTeton National Forest, Caribou-Targhee National Forest, and the Beaverhead-Deerlodge National Forest, as well as by Yellowstone National Park and Grand Teton National Park. AMS ${ }^{14} \mathrm{C}$ dates obtained directly on the wooden shafts provide temporal resolution for ice patch hunting and, in concert with temporally diagnostic chipped stone projectile points, suggest persistent use of the alpine writ large. More specifically, in concert with the remains of hunted animals, we now have a firm picture of bighorn sheep (Ovis canadensis) predation in the GYA spanning the last 4,300 calendar years. Some ice patches also contain the remains of bison (Bison bison), which have not yet been definitively associated with human hunting.

\section{Background}

In North America, ice patch archaeology refers to the study of anthropogenic materials recovered in association with small, relatively stable areas of retreating snow and ice (e.g., Dixon et al. 2005; Hare et al. 2004; Lee et al. 2014). Researchers in Europe frequently refer to this field as "glacial archaeology" (e.g., Equinox 2013; Hafner 2012). As in other parts of the world, global warming is causing perennial ice patches in the Rocky Mountains to melt, which is resulting in the release of ancient archaeological materials that, until recently, were in frozen stasis. Reckin (2013) collates and compares much of the worldwide ice patch data acquired up to 2011. Recently, the Glacier National Park Ice Patch Project (GCRMG 2015), a collaborative effort involving the National Park Service; Universities of Wyoming, Colorado, and Arizona; the Blackfeet Nation; and the Confederated Salish and Kootenai Tribes, began hosting map-based links to ice patch projects and news stories worldwide.

Ice patches are areas of permanent snow and ice that survive the summer months as a result of drifted, wind-blown snow (Figure 1). They are not massive enough to become glaciers, although snow in these locations can turn into névé or firn ice through freeze-thaw cycles and compaction. Unlike ice patches, glacial ice flows and any material deposited in the glacier's accumulation zone is conveyed to the ablation zone over a period of decades to centuries, where it will again be exposed to the elements.

Following VanderHoek et al. (2012), GYA ice patches can be classified using the morphological classes defined by Lewis (1939) that reflect underlying topography and snow depositional processes. In general, archaeologically productive ice patches in the GYA are "transverse," as in Figure 1, in that they lie horizontally on a slope below the crest of a ridge. Exceptions to this morphology 


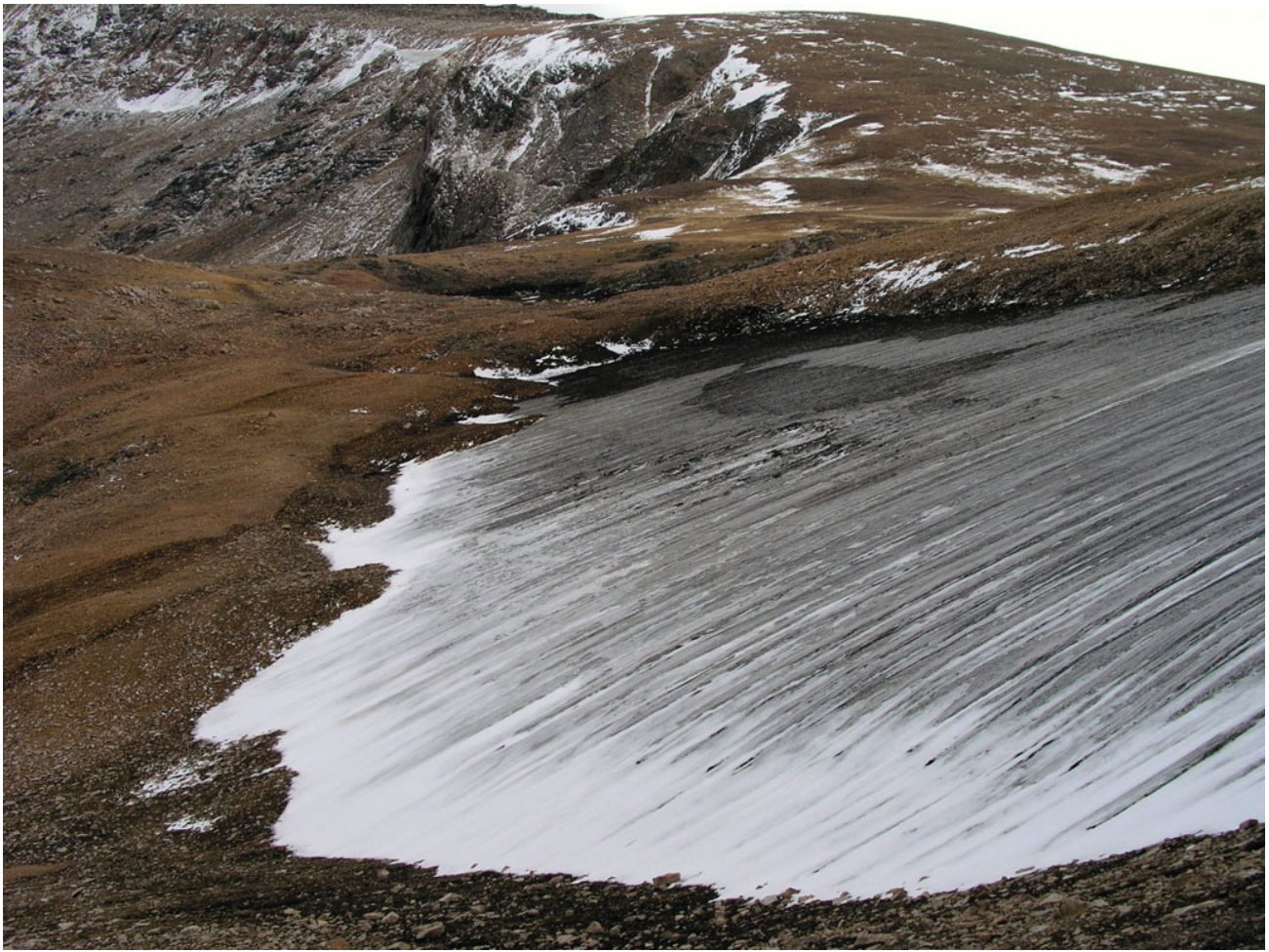

Figure 1. One of two ice patches associated with archaeological site 48PA3147. (Color online)

are infrequent, and only one archaeological site in our sample (24CB2247) is located at a "longitudinal" ice patch that appears as more of a vertical or downward-trending gully. Archaeologically productive ice patches tend to experience minimal runoff from above/upslope sources and are not associated with moving landforms, e.g., rock glaciers. They also tend to have an east-facing or northeast-facing aspect on a rolling landform that serves as a source of windblown snow and provides solar shielding. The landform must provide sufficient topographic shielding from the sun so that the seasonal input of windblown snow on the ice patch persists all year but does not thicken enough to become a glacier. In some instances, the late afternoon shadow cast by the summer sun matches the downslope outline of the permanent ice core (Lee and Benedict 2011). Additional descriptions regarding the nature of ice patch sites in the GYA are available in Lee (2012), Lee et al. (2014) and Lee and LaPoint (2015).

In the GYA, ice patches are generally found in remote, alpine areas. Most archaeologically productive ice patches occur below 3,200 m; however, sites have been identified as high as 3,414 m (Lee 2012; Rachel Reckin, personal communication 2015). To date, nine unique shafts and/or foreshafts have been recovered at five sites in the GYA (Table 1). An additional nine ice patches contain other types of artifacts, including temporally diagnostic chipped stone projectile points that will be addressed below (Lee 2009, 2014a). As of the end of 2014, a total of 14 ice patch sites with firm evidence of human use were known in the GYA. Three of the five sites containing organic dart or arrow shafts/fragments (48PA3147, 48PA3375 and 24CB2246) have a transverse (horizontal or cross-slope) morphology (sensu Lewis 1939) and similar elevation (average of $3,177 \mathrm{~m}$ ), while a fourth site, 24CB2247, lies at roughly the same elevation, but has a longitudinal (vertical or uphill-downhill) morphology. The fifth site, 24CB2175, has a transverse morphology and is notably higher at $3,414 \mathrm{~m}$.

Today, ice patches tend to exist at or above treeline; however, throughout the GYA, 
Table 1. Chronologically Ordered Shaft Samples from Ice Patch Sites in the GYA.

\begin{tabular}{|c|c|c|c|c|c|c|}
\hline $\begin{array}{l}\text { Site } \\
\text { Number }\end{array}$ & $\begin{array}{l}\text { Catalog } \\
\text { Number }\end{array}$ & $\begin{array}{l}\text { Radiocarbon } \\
\text { Date (B.P.) }\end{array}$ & $\begin{array}{c}\text { Median } \\
\text { Probability } \\
(\text { cal B.P.) })^{\mathrm{a}}\end{array}$ & Description $^{\mathrm{b}}$ & $\begin{array}{l}\text { Maximum } \\
\text { Diameter } \\
(\mathrm{mm})\end{array}$ & Genus \\
\hline $24 \mathrm{CB} 2246$ & 24CB2246.1 & $\begin{array}{l}215 \pm 20 \\
\quad \text { (CURL-9656) }\end{array}$ & 169 & Shaft fragment & 13.8 & $\begin{array}{r}\text { Betula sp. } \\
\text { (Birch) }\end{array}$ \\
\hline 48PA3147 & 48PA3147.1 & $\begin{array}{l}1169 \pm 30 \\
(\text { NZA-32327) }\end{array}$ & 1099 & Shaft fragment & 13.5 & $\begin{array}{r}\text { Betula sp. } \\
\text { (Birch) }\end{array}$ \\
\hline $24 \mathrm{CB} 2175$ & 24CB2175.1 & $\begin{array}{l}1393 \pm 30 \\
\quad(\mathrm{NZA}-32326)\end{array}$ & 1306 & Shaft fragment & 11.4 & $\begin{array}{l}\text { Pinus sp. } \\
\text { (Pine) }\end{array}$ \\
\hline 48PA3375 & YELL-210553 & $\begin{array}{l}2900 \pm 20 \\
\quad(\text { CURL-17666) }\end{array}$ & 3031 & $\begin{array}{l}\text { Dart foreshaft or } \\
\text { Mid-shaft }\end{array}$ & 9.9 & $\begin{array}{r}\text { Betula } \text { sp. } \\
\quad(\text { Birch })\end{array}$ \\
\hline 48PA3147 & 48РA3147.9 & $\begin{array}{l}3985 \pm 20 \\
\quad(\text { CURL-11673) }\end{array}$ & 4478 & $\begin{array}{l}\text { Possible arrow } \\
\text { shaft, likely } \\
\text { articulates with } \\
\text { 48PA3147.10 }\end{array}$ & 7.9 & $\begin{array}{l}\text { Salix sp. } \\
\text { (Willow) }\end{array}$ \\
\hline 48PA3147 & 48PA3147.10 & $\begin{array}{l}4130 \pm 15 \\
\quad(\text { CURL-20143) }\end{array}$ & 4675 & $\begin{array}{l}\text { Shaft fragment, } \\
\text { likely articulates } \\
\text { with 48PA3147.9 }\end{array}$ & 8.3 & $\begin{array}{l}\text { Salix sp. } \\
\quad \text { (Willow) }\end{array}$ \\
\hline $24 \mathrm{CB} 2247$ & 24CB2247.1 & $\begin{array}{l}4380 \pm 20 \\
\quad(\text { CURL-13524) }\end{array}$ & 4928 & Dart shaft & 19.8 & $\begin{array}{l}\text { Abies sp. } \\
\text { (Fir) }\end{array}$ \\
\hline 48PA3375 & YELL-210552 & $\begin{array}{l}4455 \pm 25 \\
\quad(\text { CURL-17661) }\end{array}$ & 5126 & Shaft fragment & 9.4 & $\begin{array}{l}\text { Salix sp. } \\
\quad \text { (Willow) }\end{array}$ \\
\hline 48PA3147 & 48PA3147.6 & No date & - & $\begin{array}{l}\text { Dart shaft fragment, } \\
\text { likely articulates } \\
\text { with 48PA3147.7 } \\
\text { and } .8\end{array}$ & 18.9 & $\begin{array}{l}\text { Betula sp. } \\
\text { (Birch) }\end{array}$ \\
\hline 48РA3147 & 48РA3147.7 & $\begin{array}{l}6695 \pm 20 \\
\quad(\text { CURL-9640) }\end{array}$ & 7572 & $\begin{array}{l}\text { Dart shaft fragment, } \\
\text { likely articulates } \\
\text { with 48PA3147.6 } \\
\text { and } .8\end{array}$ & 17.1 & $\begin{array}{l}\text { Betula sp. } \\
\text { (Birch) }\end{array}$ \\
\hline 48РA3147 & 48PA3147.8 & $\begin{array}{l}6560 \pm 40 \\
\quad(\text { NZA-32328) }\end{array}$ & 7466 & $\begin{array}{l}\text { Dart shaft fragment, } \\
\text { likely articulates } \\
\text { with } 48 \mathrm{PA} 3147.6 \\
\text { and } .7\end{array}$ & 17.4 & $\begin{array}{r}\text { Betula sp. } \\
\text { (Birch) }\end{array}$ \\
\hline 48PA3147 & 48PA3147.12 & $\begin{array}{l}9230 \pm 25 \\
\quad(\text { CURL-9635) }\end{array}$ & 10443 & Dart foreshaft & 12.5 & $\begin{array}{r}\text { Betula sp. } \\
\text { (Birch) }\end{array}$ \\
\hline
\end{tabular}

${ }^{a}$ Single point calibrated median ages were obtained from the online executable version of Calib 7.1 (http://calib.qub.ac.uk/calib/).

${ }^{\mathrm{b}}$ Artifacts in gray shading are presumed to refit as described in the text and are considered as a unit/single artifact in our analysis.

numerous ice patches contain in situ rooted stumps and tree trunks. These large-timber trees are distinct from the stunted and deformed krumholtz that typify treeline today, indicating that treeline was significantly higher at times during the past (Bunn et al. 2004; Carrara 2011:Appendix A; Carrara and McGeehin 2015; Lee 2013, 2014a; Morgan et al. 2014). Ice bound trees also occur outside the GYA, including along the Colorado Front Range (Benedict et al. 2008; Brunswig 2014; Lee and Benedict $2012^{1}$ ). This in situ rooted wood is invariably of alpine species, e.g., whitebark pine (Pinus albicaulis), which helps to differentiate it from the wood types generally restricted to lower elevations, e.g., birch (Betula sp.), primarily used to make hunting weapons.

Ice patch sites are invariably on public land administered by the federal government, and their contents are afforded legal protections by federal and state laws ranging from the Archaeological Resources Protection Act (ARPA) to Statutes 641 (Theft of Government Property) and 1163 (Theft from Indian Tribal Organizations). Sadly, ice patch archaeological sites are subject to unregulated collecting, with 
instances of significant theft and the attendant loss of contextual data known from Alaska to California (e.g., Sahagun 2015). The ice patch phenomenon transcends the jurisdictional boundaries that divide the GYA. In 2012, the Greater Yellowstone Coordinating Committee (GYCC), which emphasizes research on crossboundary issues, initiated a GYA-wide study to: (1) identify the highest potential snow and ice patches on GYA partner lands, (2) organize an aerial survey to photo-document as many of these locations as possible during their point of maximum annual melt in late summer/early fall, and (3) to generate a report for resource managers identifying the most promising ice patch resources so that they can be monitored in subsequent years (Lee 2014b). Out of the thousands of ice patches located within the $62,000 \mathrm{~km}^{2}$ comprising the GYA, the project identified 456 prospective ice patches with archaeological and/or paleobiological potential (Lee 2014b). Copies of the report and associated GIS and ArcGIS shapefiles, as well as Google Earth $\mathrm{kml}$ files, were shared with all cultural resources staff managing lands in the GYA. Following initial contacts with the Crow Tribe in 2006 and 2007 (and regular updates by project partner Halcyon LaPoint, archaeologist for the Custer-Gallatin National Forest), Craig Lee and Shane Doyle (Crow) shared details of the project with representatives from the Northern Cheyenne, Shoshone-Bannock, and Eastern Shoshone tribes. These visits revealed that changes in the alpine plant communities-as demonstrated through the analysis of lag deposits in ice cores (Lee et al. 2015)-were a topic of interest. As of 2015, at least five independent groups of archaeologists are now working on ice patch-related research in the GYA, including archaeologists from the Jackson History Museum (Anderson 2014; Sgouros and Stirn 2015), Office of the Wyoming State Archeologist (Peterson 2015), the University of Wyoming and the Greybull River Sustainable Landscape Ecology Project/Park County Historical Society (e.g., Baker 2016; Kolb 2015) and more (e.g., Vlcek 2015). The level of interest and the contributions generated by these teams bode well for ice patch research in the GYA; however, with the exception of the Colorado Front Range,
Olympic National Park, and Glacier National Park, ice in the rest of the conterminous United States remains terra incognita with respect to ice patch archaeology.

\section{GYA Ice Patch Hunting Implements and Wood Analysis}

Hunting implements recovered directly on melting ice or in the forefield (downslope) or lateral margins of GYA ice patches include dart and arrow shaft fragments and foreshafts. Many of the wooden implements are represented only by broken specimens, which limits their technical description; however, one attribute that can be distinguished across the entire assemblage is wood type (genus). All of the wooden dart, arrow, and foreshaft artifacts found in the GYA ice patches through 2014 have been analyzed by paleobotanists, including Jeffery Lukas and Kathryn Puseman. ${ }^{2}$ Puseman made taxonomic identifications using the standard procedure of splitting or cutting small fragments of the artifacts to expose three distinct views of the wood: transverse or cross-section, tangential, and radial (Figure 2). She then examined fragments using transmitted light microscopes at magnifications ranging from 70 600x. An AmScope 10MP microscope digital camera recorded images. Establishment of genus occurred by comparing anatomical features to those found in standard wood identification manuals (Carlquist 1988; Hoadley 1990; Panshin and de Zeeuw 1980), on Internet websites (InsideWood 2004), and in modern comparative specimens. We chose to make identifications to the genus level because it is not possible to reliably distinguish one species from another based on wood anatomy for many of the taxa.

\section{Shaft Descriptions}

Two wood shafts were recovered at site 48PA3375 (Lee 2014a). Shaft fragment 1 (YELL-210552) dates to $4455 \pm 25$ B.P. and is made from willow (Salix sp.) (Figure 3a). Willow is a woody, dicot angiosperm with vessels exhibiting large, alternate intervessel pitting, simple perforation plates, and heterocellular rays 


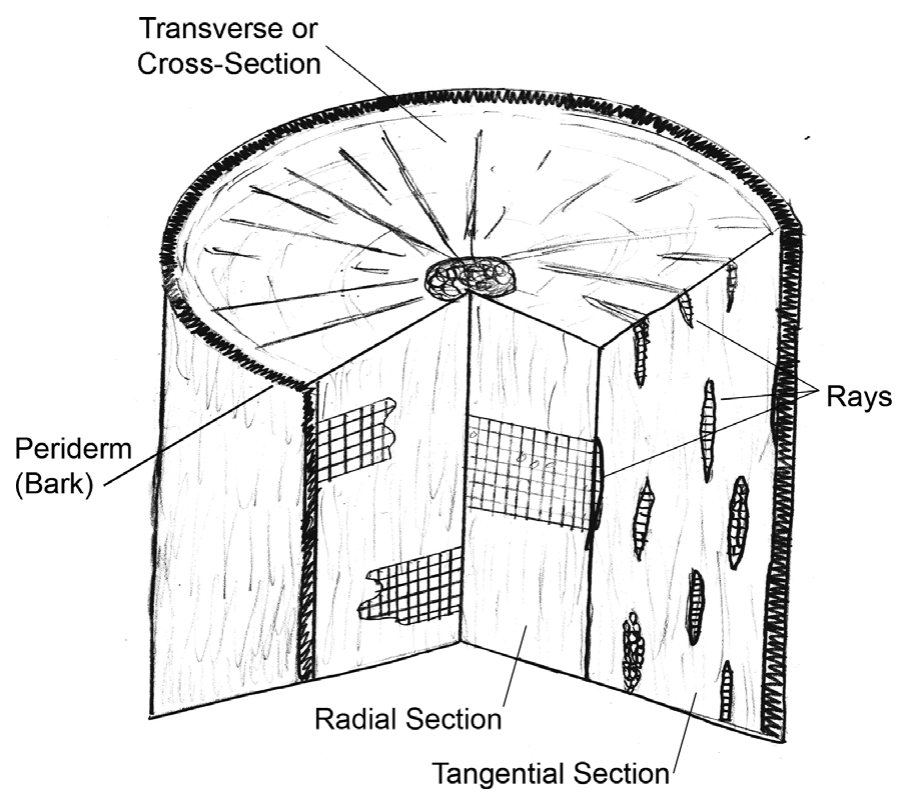

Figure 2. Wood anatomy discussed in text.

that contain both procumbent and upright cells exhibiting large ray-vessel pits (Figure $3 b$ ). The rays are also unicellular, meaning that they are only one cell in width. Shaft 2 (YELL210553) is a complete foreshaft (or possibly a midshaft) with a conical base dating to 2900 \pm 20 B.P. It measures $39.4 \mathrm{~cm}$ in total length. It was made from birch (Betula sp.), which is also a woody, dicot angiosperm with vessels (Figure 3c). It is distinguishable from willow in that the vessel walls have extremely small intervessel pits that are much smaller than those of willow, sclariform perforation plates, and multiseriate rays, up to five cells in width (Figure 3d). Two parallel oblique lines near the conical base of the foreshaft likely represent ownership or property marks. Similar marks have been found on two other GYA shafts (Lee 2010, 2012). Ethnographic observations indicate that ownership marks can be found on hunting weapons, including the portion designed to remain in the bodies of large game, e.g., foreshafts, and that they typically consist of simple lines that can be specific to either an individual or a community (Boas 1899). In her study of Late Prehistoric ownership marks in northwestern Alaska, Reynolds (1989:89) notes that, in addition to hunting equipment, they can occur on a variety of other tools ranging from pots to stored meat. Future studies of ownership marks could inform on aspects of social structure, inheritance, and ethnicity (e.g., Reynolds 1989:103). In the GYA, one of the shaft fragments with ownership marks might be a main shaft or a fragment of a single-piece weapon shaft, e.g., a dart shaft with no foreshaft, ergo it is not necessarily foreshafts alone that bear ownership marks. Since we do not have enough data to make a firm statement on this, we simply call attention to the existence of the marks.

Sites 24CB2246 and 24CB2247 are within 1.3 $\mathrm{km}$ of each other. Site $24 \mathrm{CB} 2246$ is associated with the largest ice patch recorded in the GYA. It contained a conically shaped shaft fragment made from a birch (Betula $\mathrm{sp}$.) stave (24CB2246.1) that dates to $215 \pm 20$ B.P. (Lee 2012). As of 2014, this ice patch still holds a significant volume of snow and ice. The artifact was recovered in an area of organic-rich lag along the lateral margin of the ice patch. Site 24CB2247 contained a deteriorated shaft fragment (24CB2247.1) that dates to $4380 \pm$ 20 B.P. (Lee 2012). It was made from a fir (Abies sp.) sapling, as evidenced by the fact 

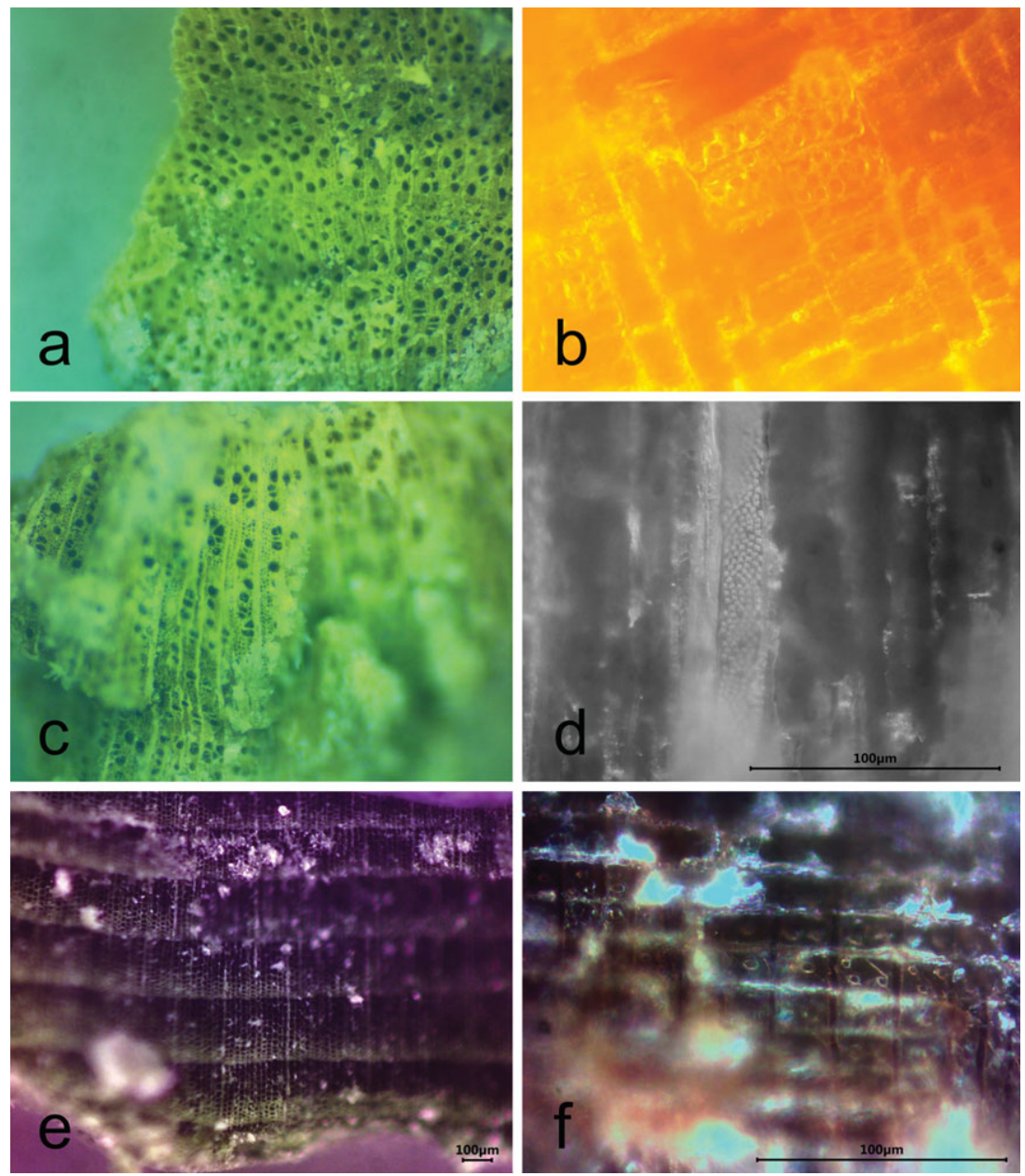

Figure 3. Sample YELL-210552, Salix sp. (willow): (a) cross-section view, 70x; (b) heterocellular ray showing both procumbent cells and upright cells with large pits, radial view, 600x. Sample YELL-210553, Betula sp. (birch): (c) cross-section view, 70x; (d) minute intervessel pitting, tangential view, 600x. Sample 24CB2247.1, Abies sp. (fir): (e) cross-section view, 70x; (f) taxodioid cross-field pitting, 600x. (Color online)

that it is a conifer with tracheids but no resin canals (Figure 3e). It also has taxodioid crossfield pitting, which can be seen at a magnification of $600 \mathrm{x}$ in the radial view (Figure 3f). The sapling was trimmed of its branches and appears to have a purposefully beveled end, which may have functioned as a scarf joint allowing it to be mated to a correspondingly beveled piece. Scarf joints can be used to connect main shafts to foreshafts, as well as to link two pieces of wood together to make a longer shaft.

Site 24CB2175 contained a shaft fragment (24CB2175.1) that dates to $1393 \pm 30$ B.P. (Lee 2012). It is unique in that it was recovered at $3,414 \mathrm{~m}$, which is more than $250 \mathrm{~m}$ above modern treeline as measured using Google Earth imagery. This argues strongly for its presence in the ice patch being anthropogenic in origin. It is consistent in overall morphology with other shafts, and it appears to have been trampled by an ungulate when it was saturated based on the presence of a bend consistent with an animal hoof. Many GYA ice patch artifacts bear evidence of trampling damage, including deeply impressed hoof marks that must have been made when the artifacts were saturated. In some situations, saturation likely helped to preserve the artifacts, which may have simply snapped 


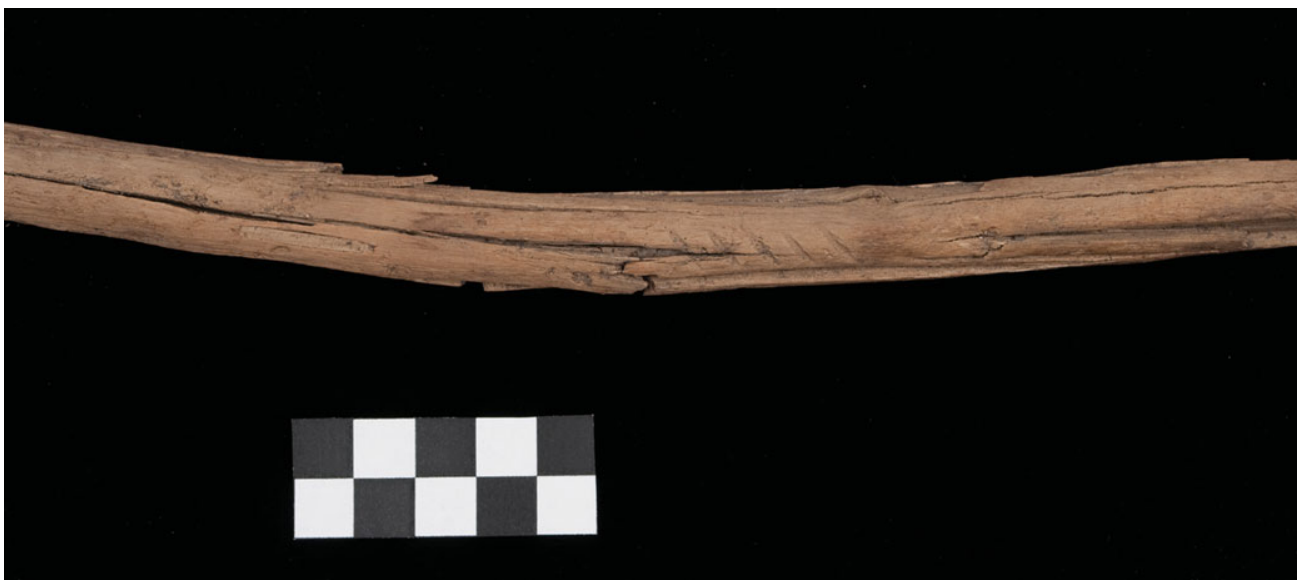

Figure 4. Detail of sapling shaft fragment (48PA3147.7) with five parallel oblique ownership marks. (Photo by Tara L. Hornung) (Color online)

to pieces had they not been waterlogged. The artifact is made from a pine (Pinus sp.) sapling, a conifer with resin canals that can be seen in both the cross and tangential section views, as well as pinoid cross-field pitting. The somewhat deteriorated nature of the wood precluded a clear view of the ray tracheids in this particular fragment; therefore, we cannot identify it as a soft or hard pine.

The remaining four shafts and fragments presented in Table 1 were recovered from site 48PA3147. One of the shafts is represented by three distinct pieces (48PA3147.6, .7, and .8) that appear to be similar in age, diameter, and weathering but cannot be refitted due to weathering and warping at the broken ends. The three pieces are treated as one artifact in the present analysis. Two of the three fragments were radiocarbon dated and produced similar dates. One dates to $6695 \pm 20$ B.P. and exhibits five parallel oblique lines that likely represent ownership marks (Figure 4). The other dated fragment has a tapered/beveled end returned an age of $6560 \pm 40$ B.P.

The youngest shaft recovered at the site, 48PA3147.1, dates to $1169 \pm 30$ B.P. It is made of a birch (Betula sp.) sapling trimmed of its branches. The oldest artifact from the site, 48PA3147.12, dates to $9230 \pm 25$ B.P. and is a complete dart foreshaft made on a birch sapling. It is $1.07 \mathrm{~m}$ in total length. Two groups of three evenly spaced lines on opposing sides of the artifact are interpreted as ownership marks (for photos and additional description, see Lee [2010, 2012] and for discussion of its replication and use, see McConnell and Lee [2013]).

The remaining two shafts from the site, 48PA3147.9 and 48PA3147.10, are both made on willow (Salix sp.) and date to $3985 \pm 20$ B.P. and $4130 \pm 15$ B.P., respectively. The shafts are similar in age, diameter, and weathering, but cannot be refitted due to weathering and warping at the broken ends. The two pieces are treated as one artifact in the present analysis. Fragment 48PA3147.9 appears to have a Vshaped nock suggestive of bow and arrow technology (Figure 5). A variety of nock styles are known from Native American archery, including U-shaped, V-shaped, and an "Open U" in which the bottom of the cut is round, but the sides are flared (Alix et al. 2012:107). U-shaped nocks dominate the Canadian ice patch assemblage (Alix et al. 2012), whereas Ushaped and V-shaped nocks occur with similar frequency in Alaskan ice patches (e.g., Dixon et al. 2005). If this fragment is an arrow, it is far older than the widely accepted date range for the introduction/adoption of bow and arrow technology in the region, which most investigators place around 1500 B.P. based on the appearance of new types of projectile points and the occurrence of more diminutive forms (Kornfeld et al. 2010:130). Arrow shafts of similar age have been reported in the north, 


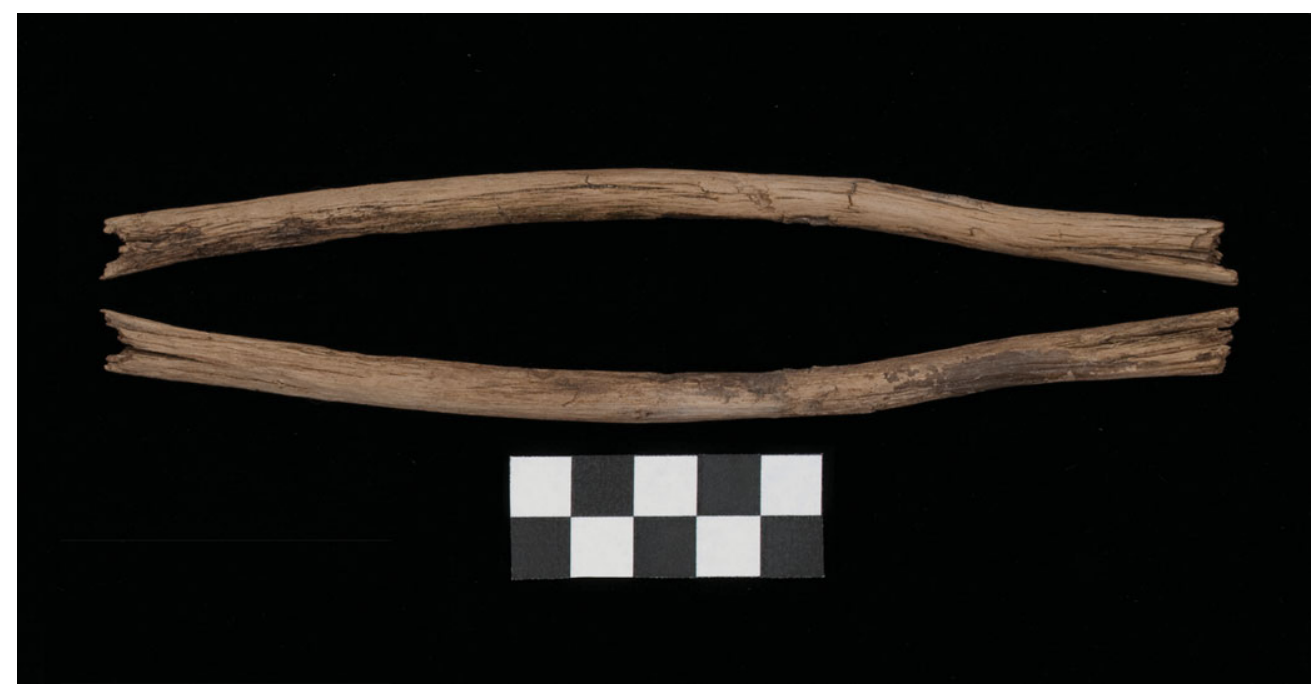

Figure 5. Two views of Salix sp. (willow) shaft fragment (48PA3147.9) showing possible nock at left (photos by Tara Hornung). (Color online)

including one with a U-shaped nock from the southern Yukon Territory that has two assays of $3510 \pm 70$ B.P. and $3600 \pm 40$ B.P., respectively (Hare et al. 2004; Hare et al. 2012), and a ca. 4000-radiocarbon-year-old arrow shaft from the Wrangell Mountains of Alaska, some $400 \mathrm{~km}$ to the west of the Yukon artifact (E. James Dixon, personal communication 2016).

Hare et al. (2012) posit that the presence of arrow technology in the Yukon during this time period may represent the influence of the bow and arrow technology of Arctic Small Tool tradition people from the western Arctic (Anderson 1984). Although the GYA specimen is nearly $2,600 \mathrm{~km}$ to the south, the two areas are geographically linked by the arc of the Rocky Mountain Front, and it is possible that a cultural or technological connection, albeit brief, may have existed. Other evidence for a connection between the far north and mid-latitudes has come to light in recent years. Work by Wilson et al. (2011) suggests that the microblade technology originally described by Wormington and Forbis (1965) in the High River area of southernmost Alberta, Canada, likely represents a derivative of an Arctic/SubArctic microblade tradition that was coeval with the late Paleoindian Cody complex based on associated diagnostic projectile points. Lee et al. (2016) describe further occurrences of microblade technology even further south during the late Paleoindian period in Montana at the Mammoth Meadows and Myers-Hindman sites. If 48PA3147.9/48PA3147.10 represents the presence of bow and arrow technology, its subsequent disappearance is no less intriguing. A possible interpretation might be that the technology was not significantly more suited to the hunting demands or group dynamics of the time and, thus, after a trial, was abandoned.

\section{Materials Analysis}

Most of the shafts recovered from sites in the GYA represent dart shafts that would have been propelled by an atlatl. VanderHoek (1998:83) notes that "between the atlatl and the dart, the dart has been found to be the most critical part of the throwing equation." There are many variables that affect the performance of a dart; however, experiments have shown that the dart's "spine" (ability to flex or degree of stiffness), has generally been seen as the most important (Cundy 1989:64; Hayes 1994; Perkins 1992; Schuh et al. 1997:32-33; Tolley and Barnes 1979:70-71; Whittaker 2010). In bow and arrow technology, an arrow must be properly spined in order to compress upon release, oscillate, and then rapidly dampen to fly straight. So too a dart must also be able to flex, then rapidly abate its oscillations (Hayes 1994; VanderHoek 1998:83). 
One factor that affects how the dart will flex is the type of wood used in its construction. We can measure how well an arrow or dart might perform using indices ( $\delta$ ' and $\delta$ ) of wood suitability based on Beckhoff (1965:54-56; see also Alix et al. 2012), for species known to have been used for making arrows in western North America. These numerical indices provide a way to compare different species of wood for their suitability as arrow shafts. Table 2 provides adaptability indices for several wood species found in western North America, some of which may have been used as shafts in the GYA. Although Beckhoff's formula was intended to measure arrow shafts, it is notable that woods with a good to excellent adaptability index were also used in construction of the dart shafts and shaft fragments recovered from ice patch sites in the GYA.

Of the nine shaft samples examined from the GYA, five are made of birch, two from willow, one from fir, and one from pine (Table 1). Woods that are good for making arrows also appear to be good for making darts and foreshafts. Many of the variables used in Beckhoff's formula have been determined only for commercially graded lumber, and, as a consequence, not all of the wood types that might have been selected for use as shafts (such as species of willow) can be assessed to the same degree. Based on the long duration of birch shaft usage, it appears that Native American groups in the GYA preferentially selected this material through time, although other materials were used.

\section{Temporally Diagnostic Projectile Points}

In addition to organic materials, extensive lithic assemblages including projectile points and point fragments have been found in ice patch forefields. For example, temporally diagnostic chipped stone projectile points identified at the 48PA3376 ice patch and others include variants of Oxbow and Pelican Lake types (e.g., Lee 2014a; Vivian and Mitchell 2005:Plate A-1E). Both point styles were likely used with atlatl darts (Peck 2011; Wettlaufer 1955). Oxbow projectile points have shallow side-notches with incurved bases and rounded ears. In the GYA they date to the Middle Plains Archaic with a core temporal span from ca. 5700 to 3500 years B.P. (Aaberg et al. 1999;
Greiser et al. 1985; Kornfeld et al. 2010). Pelican Lake projectile points date to the Late Plains Archaic and are corner-notched and date from ca. 3000 to 1500 B.P. (Frison 1991:101-103). These chronological markers augment the date range obtained on direct ${ }^{14} \mathrm{C}$ measurements made on shafts and potentially expand the temporal window for use of these features.

In some instances, upslope plateaus near transverse ice patches, such as at 48PA3375, are covered with thousands of chipped stone artifacts made on brightly colored cherts, silicified woods, and obsidians (Lee 2014a). Many of the artifacts are fragments of formal tools and utilized flakes - the type of detritus associated with repeated occupations of seasonal campsites. Vertical exposures in the 20- to 30 $\mathrm{cm}$-thick sediment cap at 48PA3375 suggest that some of these sediments may be stratified and offer an interpretable sequence (Lee 2014a). In other alpine locations, researchers have reported buried soils in these contexts (Mitchell 2012). Benches downslope from ice patches can also hold lithic scatters (Lee 2009).

\section{Prey}

Based on the ice patch record, the seasonally rich forage of the $3,000 \mathrm{~m}$ or more elevation plateaus of the GYA have attracted large ungulates such as bighorn sheep (Ovis canadensis), bison (Bison bison), elk (Cervus elaphus), and mule deer (Odocoileus hemionus) for millennia. The remains of bighorn sheep and bison are the most commonly encountered species in the lateral and forefield margins of GYA ice patches (Lee 2009, 2013, 2014a). This is true in other parts of the Rocky Mountains as well, including the Colorado Front Range (Lee and Benedict $2012^{1}$; Lee et al. 2006). Why ice patches at these latitudes attract animals remains an open question, with possibilities including thermal regulation (cooling), hydration, the need to escape pests such as black flies (Simuliidae) and mosquitoes (Culicidae) (Greg Johnson, personal communication 2015), or a cyclical return to areas where scat from previous visits acts as fertilizer creating a positive feedback of enriched forage. Many GYA ice patches, such as the one depicted in Figure 6, do not contain material of a 
Table 2. Wood Adaptability Coefficients $\left(\delta^{\prime}\right)$ and Ratings.

\begin{tabular}{|c|c|c|c|c|c|c|c|c|c|c|}
\hline $\begin{array}{l}\text { Scientific } \\
\text { name }\end{array}$ & $\begin{array}{l}\text { Common } \\
\text { name }\end{array}$ & $\begin{array}{l}\text { Young's } \\
\text { Modulus } \\
\text { (E) } \mathrm{kg} / \mathrm{cm}^{2}\end{array}$ & $\begin{array}{c}\text { Specific } \\
\text { weight } \\
\left(\mathrm{r}_{15}\right) \mathrm{g} / \mathrm{cm}^{3}\end{array}$ & $\begin{array}{c}\text { Radial } \\
\text { shrinkage } \\
\left(\mathrm{a}_{\mathrm{r}}\right) \%\end{array}$ & $\begin{array}{l}\text { Tangential } \\
\text { shrinkage } \\
\quad\left(a_{t}\right) \%\end{array}$ & $\delta^{\prime a}$ & $\begin{array}{c}\text { Fiber } \\
\text { straightness }\end{array}$ & Cleavability $^{\mathrm{c}}$ & $\delta^{\mathrm{d}}$ & Rating \\
\hline Abies concolor & White fir & 10,4406 & .416 & 3.3 & 7.0 & 1.18 & 1 & .9 & 1.06 & Very good \\
\hline Abies grandis & Grand fir & 10,7570 & .448 & 3.4 & 7.5 & 1.09 & 1 & .9 & .98 & Good \\
\hline Abies lasiocarpa & Subalpine fir & 9,3086 & .529 & 2.6 & 7.4 & .62 & 1 & 1 & .62 & Not desirable \\
\hline Picea engelmannii & Engelmann spruce & 9,6250 & .384 & 3.8 & 7.1 & 1.34 & 1 & .9 & 1.21 & Excellent \\
\hline Picea glauca & White spruce & 10,0542 & .449 & 4.7 & 8.2 & 1.28 & 1 & .9 & 1.16 & Very good \\
\hline Pinus contorta ${ }^{\mathrm{e}}$ & Lodgepole pine & 9,4214 & .465 & 3.6 & 5.4 & 1.35 & 1. & .9 & 1.22 & Excellent \\
\hline Pinus edulis & Pinyon pine & 8,0150 & .592 & 4.6 & 5.2 & 1.20 & .5 & .8 & .48 & Not desirable \\
\hline Pinus flexilis & Limber pine & 8,2259 & .449 & 2.4 & 5.1 & .86 & 1 & 1 & .86 & Good \\
\hline Pinus monticola & Western white pine & 10,2648 & .432 & 4.1 & 7.4 & 1.32 & 1 & 1 & 1.32 & Excellent \\
\hline Pinus ponderosa & Ponderosa pine & 9,0696 & .449 & 3.9 & 6.2 & 1.27 & 1 & 1 & 1.27 & Excellent \\
\hline Betula alleghaniensis ${ }^{\mathrm{f}}$ & Yellow birch & 14,1317 & .689 & 7.3 & 9.5 & 1.58 & 1 & .9 & 1.42 & Excellent \\
\hline Betula lenta $\mathrm{f}$ & Sweet birch & 15,2566 & .737 & 6.5 & 9.0 & 1.50 & 1 & .9 & 1.35 & Excellent \\
\hline Betula papyrifera ${ }^{\mathrm{e}}$ & Paper birch & 11,1791 & 609 & 5 & 6.9 & 1.33 & 1 & .9 & 1.20 & Excellent \\
\hline Populus tremuloides & Quaking aspen & 8,2962 & .416 & 3.5 & 6.7 & 1.04 & 1 & .8 & .83 & Good \\
\hline Salix alba ${ }^{\mathrm{g}}$ & White willow & 7,9095 & .400 & 4.2 & 7.2 & 1.15 & 1 & .8 & .92 & Good \\
\hline Salix nigra ${ }^{\mathrm{e}, \mathrm{g}}$ & Black willow & 7,1012 & .417 & 2.1 & 6.5 & .55 & No data & No data & - & Not desirable \\
\hline
\end{tabular}

${ }^{\mathrm{a}}{ }^{\prime}=\mathrm{E} / \mathrm{r}_{15} * \mathrm{a}_{\mathrm{r}} / \mathrm{a}_{\mathrm{t}} * 10^{-5}$.

${ }^{\mathrm{b}}$ Rated as $1=$ regular; $.8=$ medium; $.5=$ irregular.

${ }^{\mathrm{c}}$ Rated as $1=$ good; $.9=$ medium; $.8=$ poor.

${ }^{\mathrm{d}}$ Beckhoff's final index $(\delta)$ is the product of $\delta^{\prime}$ and values given for fiber straightness and cleavability.

${ }^{\text {e}}$ Data originally presented in Alix et al. 2012:Table 3.

${ }^{\mathrm{f}}$ Species not found in GYA but are included to show values for more than one species of Betula.

${ }^{\mathrm{g}}$ Although Salix alba is an introduced species and Salix nigra is found only in eastern North America, these species are included as the only species of Salix for which values are available. 


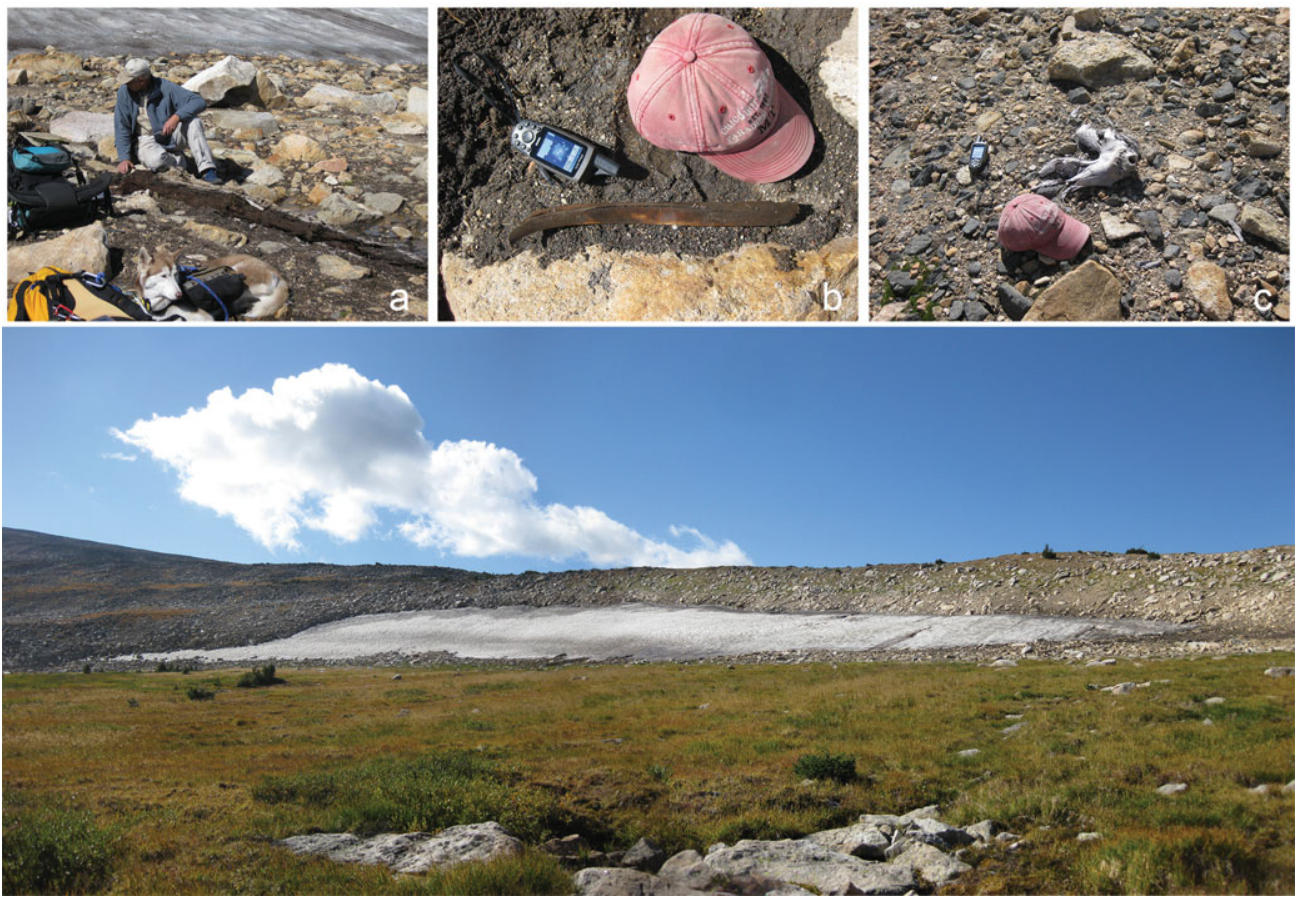

Figure 6. Main image: representative GYA ice patch showing a lush, well-watered forefield; Insets are paleobiological material observed at the ice patch: (a) trunk of a large timber fir (Abies sp.), (b) associated bison (Bison bison) rib (not collected), (c) base and horn cores of a bighorn sheep (Ovis canadensis) skull (not collected). (Color online)

definitively cultural origin; however, as described below, the presence/preservation of bighorn sheep skulls (Figure 6c) without postcranial elements could reveal the presence of humans.

The best evidence for prey selection at GYA ice patches comes from archaeological site 48PA3147 (Figure 1), which contains the remains of numerous bighorn sheep represented primarily by crania and horn sheaths. In 2007, two pieces of spirally fractured and cut-marked long bone consistent with bighorn sheep were also recovered at the site; one of the pieces was exceptionally greasy and was radiocarbon dated to $2210 \pm 25$ B.P. (Lee 2012). Lee observed skulls and horn cores at the location in 2007 and 2009 but did not collect them because their association with the archaeological materials was unclear. At that time, it was reasoned that some might relate to cultural activity but others could be the result of non-human events. (The volume of scientifically interesting material encountered during the course of a field survey can be staggering and would pose a significant curation issue if it were all collected.) Lee (2012) described the purported existence of 13 bighorn sheep skull caps and horn cores and two bison skulls collected by Dr. Don Pattie at the location in 1962. Lee attempted to locate the material for several years, but it was not until 2013 that project collaborator Weber Greiser found the errant sheep skulls and horn cores in their original field packaging at the Philip Wright Zoological Museum at the University of Montana. The two bison skulls have not been relocated. All of the sheep skulls were assigned the same catalog number by the museum: 13253 . Lee photographed the skulls and fragments and collected six samples (three bone and three horn) for radiocarbon dating. The samples were also assigned a unique identifier based on the ice patch project archive curated at the Billings Curation Center in Billings, Montana. The GNS Rafter Radiocarbon Laboratory in New Zealand processed the three bone samples, and the keratin (horn) samples were prepared at INSTAAR and dated at the Keck AMS lab. Four of the dates on 
Table 3. Radiocarbon Ages on Bighorn Sheep (Ovis canadensis) from Archaeological Site 48PA3147.

\begin{tabular}{|c|c|c|c|}
\hline Sample Number & Radiocarbon Date (B.P.) & 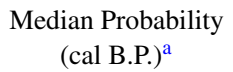 & $\begin{array}{l}\text { Description, } \\
\text { dated portion }\end{array}$ \\
\hline BCC-0727-PZ-004 & $3885 \pm 25($ CURL-17663) & 4333 & Horn sheath, keratin \\
\hline BCC-0727-PZ-003 & $3665 \pm 25($ CURL-17668) & 3993 & Horn sheath, keratin \\
\hline BCC-0727-PZ-001 & $3346 \pm 26(\mathrm{NZA}-55628)$ & 3589 & $\begin{array}{l}\text { Skull, right petrous } \\
\text { portion }\end{array}$ \\
\hline BCC-0727-PZ-005 & $3296 \pm 25(\mathrm{NZA}-55630)$ & 3521 & Skull, fragments \\
\hline 48PA3147.5 & $2210 \pm 25(\mathrm{NZA}-32961)$ & 2231 & $\begin{array}{l}\text { Spirally fractured, cut } \\
\text { marked long bone }\end{array}$ \\
\hline BCC-0727-PZ-002 & $879 \pm 23($ NZA-55629) & 781 & $\begin{array}{l}\text { Skull, right petrous } \\
\text { portion }\end{array}$ \\
\hline
\end{tabular}

${ }^{\mathrm{a}}$ Calibrated means were obtained from the online executable version of Calib 7.1 (http://calib.qub.ac.uk/calib/).

the Pattie sheep skulls cluster around 4000 B.P. and one is approximately 800 B.P. (Table 3). In Figure 7, the most complete skull (second from the top at left) dated in the 3400 B.P. range, while the more deteriorated skull fragment (third from the top at right) dated at ca. 880 B.P. The differences in preservation and age of these skulls is emblematic of the nature of ice patch materials: ice patches can contain specimens of vastly different ages exposed on the same melt surface with preservation not serving as a reliable indicator of age. We estimate the total number of skulls present at this site to be in excess of 20 .

In concert with observations made at other known bighorn sheep hunting locales in the GYA, it seems clear that bighorn sheep skulls were frequently left at kill sites. Eakin (2005:77) reports that ram skulls have been found by artifact collectors in tree branches at several sheep traps in the GYA and that a cluster of eight burned skulls were observed at a campsite/bighorn sheep processing area within ca. $300 \mathrm{~m}$ of a sheep trap (Eakin 2005:78). Frison (2004:160) describes a concentration of 25 sheep skulls associated with the remains of a badly deteriorated log fence in the GYA. This same location is mentioned in Kornfeld et al. (2010:312) with a note that very few postcranial elements were present. Nearly a dozen sheep traps, which frequently consist of drive lines made of logs that funnel the animals toward a cribbed log catch-pen, are known from the eastern flank of the Rocky Mountains alone (Frison et al. 1990; Kornfeld et al. 2010). Given the effort involved in their construction, these features were likely maintained and reused for years (Kornfeld et al. 2010:304). Tree ring dates derived from intact portions, as well as archaeological data from other mass sheep kills, indicate that these types of sites tend to date no earlier than the Late Prehistoric period, ca. 500 B.P. (Kornfeld et al. 2010). Data from the region as a whole strongly suggest that the bighorn skulls found at 48PA3147 fit into a regional pattern of sheep hunting that includes the intentional accumulation of bighorn sheep skulls at certain sites. At the site, some of the skulls date to far earlier than the Late Prehistoric skulls that others have found affiliated with wooden sheep traps, suggesting a deeper temporal depth to this pattern than has previously been observed.

In contrast to bighorn sheep, the remains of other possible prey species, such as bison, that have been found at ice patches are represented by both skulls and postcranial remains. While bison remains have been observed at more than a dozen ice patches in the GYA, thus far, only three sets have been radiocarbon dated, and all are younger than 1000 radiocarbon years B.P. They include a partial bison skeleton (BCC-0727-PZ-010) recovered at 3,400 $\mathrm{m}$ that was radiocarbon dated to $775 \pm 25$ B.P. (CURL-17669; horn sheath; $\delta^{13} \mathrm{C}=-24.1 \%$ ); a portion of a bison hind limb (BCC-0727-PZ-006) recovered at an ice patch in another location that radiocarbon dated to $698 \pm$ 23 B.P. (NZA 55631; astragalus, collagen; $\delta^{13} \mathrm{C}$ $=-19.2 \%$ ); and a bison thoracic spine with soft tissue (BCC-0727-PZ-009) recovered in a third area ca. $48 \mathrm{~km}$ north of the northern border of Yellowstone National Park that returned a 


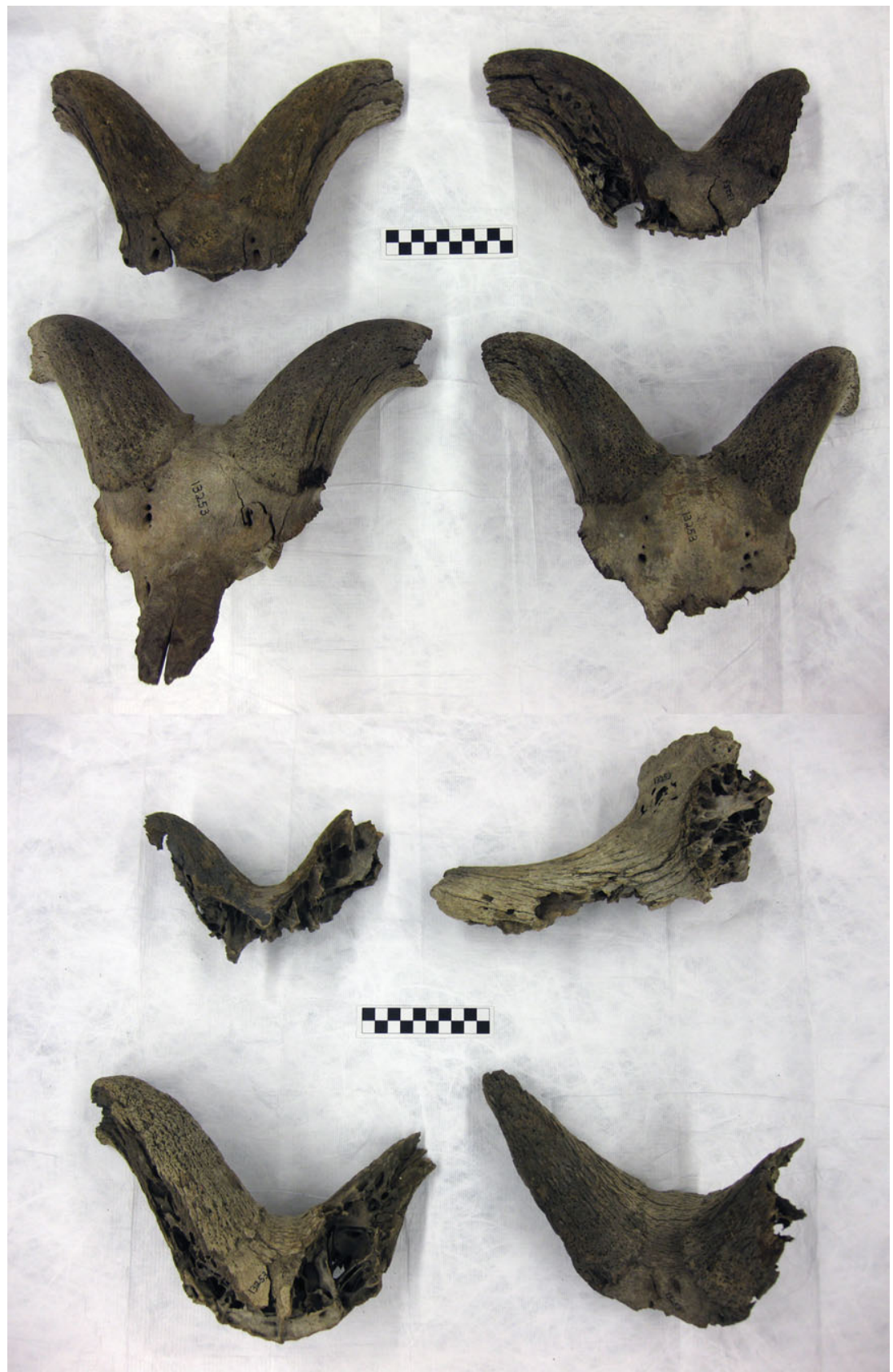

Figure 7. The eight bighorn ram sheep skulls/horn cores collected by Don Pattie in 1962; the remaining five samples collected by Pattie are horn sheathes (not pictured). (Color online)

radiocarbon-modern date (CURL-10424; soft tissue) (Lee 2013). The latter specimen is of interest because it is indicative of bison ranging well to the north of the modern "Tolerance Area" for bison in the North Management zone of the
GYA; the movement of bison outside of the confines of Yellowstone National Park is severely restricted due to concerns over the transmission of brucellosis, a disease that can cause abortion in domestic cattle (IBMP 2014). 


\section{Discussion}

The wood analysis of the shaft fragments collected from ice patches in the GYA suggests that birch (Betula spp.) was a consistent choice for ice patch hunting equipment throughout the Holocene but that other woods were also used, including willow (Salix spp.), fir (Abies spp.), and pine (Pinus spp.). Of the ranked woods (Table 2), birch is an excellent choice for making shafts and there appears to be broad continuity in its use across space and through time. In addition to those from the GYA, five of the seven dart and arrow shafts presented by Andrews et al. (2012:Table 1) from ice patches in the Northwest Territories are made of birch (Betula sp.). The remaining shafts include one made of spruce (Picea sp.) and one of Saskatoon berry (Amelanchier sp.). Hare et al. (2012) report that dart shafts in the Yukon Territory are made from birch, willow, spruce, and, in a single instance, maple (Acer sp.), with birch being the most commonly used wood. They also note that all of the birch dart shafts and foreshafts are made from split staves, while the shafts and foreshafts made from willow and spruce are natural saplings. This pattern is not replicated in the GYA collection, where some birch shafts are made from saplings and others from staves. In a study of five Neolithic arrow shafts from the Oppdal area of Norway (Callanan 2013), two are made of birch, two of pine, and one of willow. Ryd (2014) notes that birch was the preferred wood for arrows used by the Saami of Scandinavia due to its hardness.

With regard to prey selection, bighorn sheep appear to be the primary prey species at ice patches in the GYA based on the record at 48PA3147. In concert with the relative scarcity of post-cranial elements $(n=2)$, there is an obvious bias toward skulls at the site. Coupled with the presence of the organic hunting weapons, it seems parsimonious to conclude that the presence of the skulls at the site is a result of human activity. The dated bone and horn sheaths (Table 3) suggest at least three broad periods of use that can be combined with the dates on artifacts in the preceding sections. It is unclear whether these observations can be extended to instances where a single skull is observed, such as at the ice patch depicted in Figure 6, when no other obvious cultural material is present; however, such instances may warrant consideration in the future.

Although there are too few dates to make inferences about population size, as Kelly et al. (2013) have done for the nearby Bighorn Basin in Wyoming, the dates on organic tools and hunted animals nevertheless provide an absolute indication of human presence at high altitudes in the GYA at certain points in time. Figure 8 overlays a temperature curve for the GYA on the summed probability distribution of the 15 discrete dates on shafts and hunted sheep from GYA ice patches. The sample of dates is small and the absolute value of the summed probabilities is not meaningful, but the discrete intercepts are illustrative of the persistent use of alpine ice patches beginning at the onset of the neoglacial advance at ca. 5400 cal BP. The breaks in the distribution may relate to taphonomic processes that affect ice patches, or equally may indicate periods of less intense use. Efforts are underway to study the growth and persistence of ice patches through the analysis of ice cores (GCRMG 2015; Lee et al. 2015). The result of those analyses will help to characterize the growth and melt patterns of GYA ice patches, which in turn will be informative regarding the differential effects of preservation in the ice patch record. Continued research on the part of the many groups now working in the GYA will help to build the artifact and radiocarbon date set and, perhaps more importantly, serve as a model for research throughout the Rocky Mountain West.

Recovery of hunting-related artifacts and bone from GYA ice patches suggests that the presence of prey animals attracted Native American groups to these areas. While the unique plant and animal communities of the alpine are of clear ethnohistorical and modern significance to indigenous communities, no histories specific to the use of ice patches have been identified. Ice patch hunting histories, such as those reported for the Saami in Scandinavia, provide a potential analogy (Ryd 2014). At a minimum, the GYA ice patch record allows for the conceptualization of the alpine-in ancient times, at least - as an ecosystem in balance where 


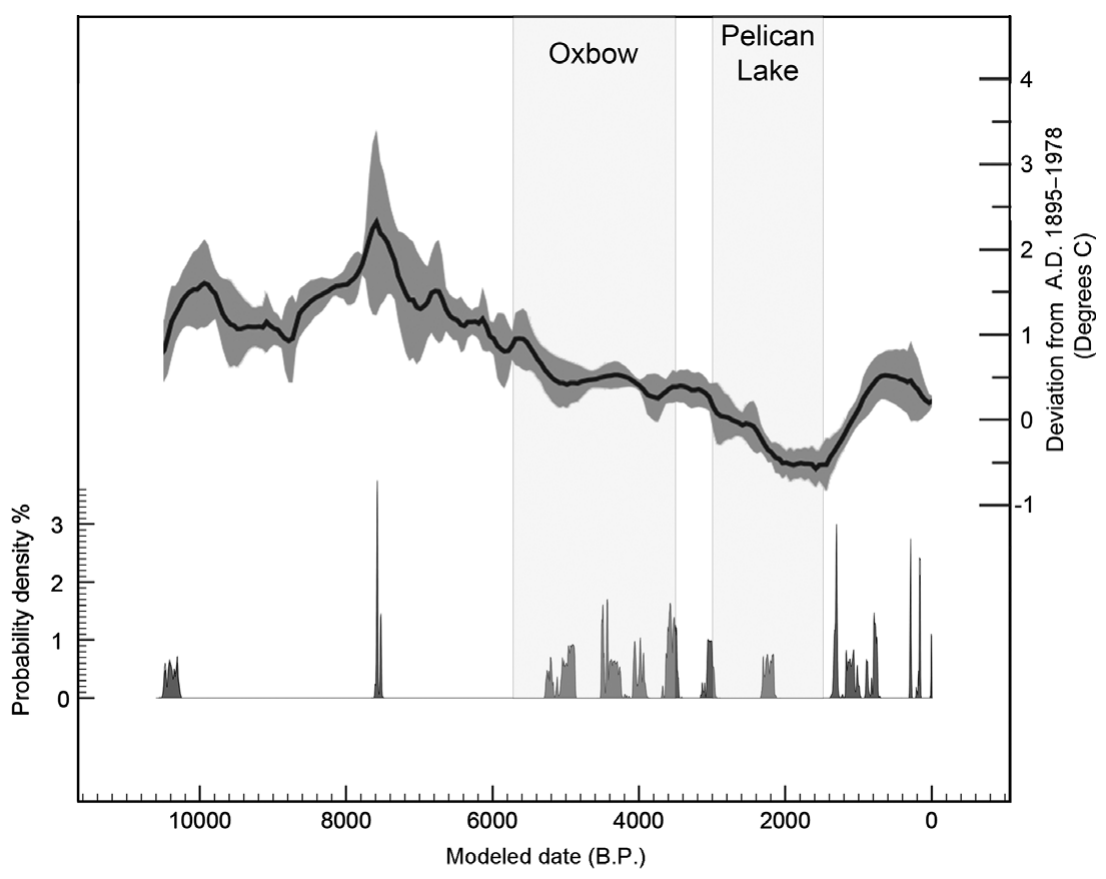

Figure 8. Summed probability distribution for dates on unique shafts and sheep created with OxCal v4.2.3 relative to temperature date from Shuman (2012) and Kelly et al. (2013) using the IntCal 13 data set (Reimer et al. 2009). The vertical gray bars reflect typologically derived date ranges for the Oxbow (left) and Pelican Lake (right) style projectile points discussed in text.

humans and animals alike took advantage of a seasonally enriched biome (Lee and LaPoint 2015). Regular use of the alpine along the Rocky Mountain Front is consistent with the oral traditions of many tribal groups, including the Salish, Kootenai, and Blackfeet.

\section{Conclusion}

High-elevation environments are among the settings most vulnerable to climate changes. If our climate continues to warm as predicted, the ancient ice in these features will continue to retreat and some may melt out completely. The ice-buried archaeological and biotic remains are highly fragile once exposed, and the need for rapid assessment and salvage of these culturally and scientifically valuable artifacts and materials has been recognized by all of the land management agencies in the GYA.

Ice patch research is a unique way to introduce people to climate change or to maintain their awareness of the issue. It brings interdisciplinary scientists, government agencies, policy-makers, indigenous groups, and the general public together around a topic that cuts across ecology, economy, and cultural traditions. It is a fundable nexus for interdisciplinary, natural, and cultural research. Archaeological data, in conjunction with the involvement of descendant communities and the analysis of collocated paleobotanical and paleontological materials, can further our insight into questions of critical archaeological interest, such as population shifts and even demography across broad regions. Organic artifacts provide context for the inorganic elements that comprise most assemblages, and key elements, such as ownership marks, make the individual recognizable in the archaeological record. The recovery of organic artifacts such as wooden weapons is particularly informative, because organic artifacts reveal more about how weapons systems operated than projectile points alone, and small fragments of organic tools can be transformed via AMS ${ }^{14} \mathrm{C}$ into a precise estimate of their age. 
The use of the ice patch record to understand alpine ecosystems is of international significance because they occur across large swaths of Europe, Asia, and South America. Well-dated chronologies of botanical material contained in ice patches allow for the investigation of interactions between human and wildlife activity, ecological diversity, and climate. While the present study allows for some insight, such as the role of bighorn sheep as a driver for the human use of ice patches, the ice patch record-and in some respects, the archaeology of the Alpine writ large-represents a data gap, because, relative to the surrounding areas, comparatively little has been done in this environment. This view is consistent with the perception of many traditional stakeholders. The integration of the ice patch record with alpine data sets, such as the landscape-scale lithic analysis being pursued by Todd (2015) and the recognition of landscape engineering in mountain environments (e.g., Scheiber and Zedeño 2015) bring us closer to answering Nabokov and Loendorf's (2004:299) charge to integrate humans into the biome and to see the GYA "as a multicultural habitat that has been visited, inhabited, shaped and instilled with meaning by American Indians for millennia."

The inter-annual variability in precipitation (snowfall) and in degree of melting, coupled with seasonal constraints and the sometimes difficult access to locations in modern-day "wilderness" areas, limits the number of survey targets that can be reached by archaeologists in a season. The field of ice patch archaeology desperately needs more researchers; within the GYA alone we have identified hundreds of prospective sites in need of survey, and there are countless other areas with permanent snow and ice in many western states. We look forward to others tackling the field of North American ice patch research.

Acknowledgments. We thank representatives from the Native American community, including Ira Matt (Salish), Francis Auld (Kootenai), John Murry (Blackfeet), Conrad Fisher and Teanna Limpy (Northern Cheyenne), Shane Doyle and Emerson Bull Chief (Crow), Darrell Shay and Leo Ariwite, (Shoshone-Bannock), and Lynette St. Clair and Orville St. Clair (Eastern Shoshone) (and many more) for their interest in the research and sincerely hope that it is of use to the tribes. We thank colleagues at the USDA Forest Service, including Halcyon LaPoint, Mike Bergstrom, Kyle Wright, Molly Westby, Jamie Schoen, J.P. Schubert, Virginia Kelly, Carl Davis, Mike Beckes, Walt Allen, Jeff Dibenedetto, and Jeremy Karchut (and many more), as well as the National Park Service, including Staffan Peterson, Tobin Roop, Ann Johnson (retired), Stacey Gunther, Sarah Hass, Christie Hendrix, and Ivan Kowski (and many more) for their vision regarding this work. We thank countless volunteers who have trekked in difficult conditions up mountainsides where there are often no contemporary human trails. We thank an anonymous board member at American Antiquity for orchestrating the review and Thomas Andrews, Robert Kelly, and two anonymous reviewers for their thoughtful comments. Colleagues Rachel Reckin and Erick Robinson provided comments on an early draft. The work was funded in part by cost shares with the U.S. Forest Service and via grants from the National Park Service administered by the Rocky Mountain Cooperative Ecosystem Studies Unit. Important funding also came from Weber Greiser and the Cody Institute of Western American Studies at the Buffalo Bill Historical Center. Last, but not least, we thank Carla Villafuerte-Griessler for translating the abstract into Spanish and María Fernanda Boza Cuadros for checking it. Ice patch research will continue in the GYA through at least 2018 supported in part by the Camp Monaco Prize, a joint award to Lee at INSTAAR and colleagues at the U.S. Geological Service and Montana State University from the Buffalo Bill Historical Center's Draper Natural History Museum, the University of Wyoming's Biodiversity Institute, and the Prince Albert II of Monaco Foundation, Monaco and USA.

Data Availability Statement. All physical collections are housed at Billings Curation Center in Billings, Montana, or at the Yellowstone National Park Repository in Gardiner, Montana. Copies of all ice patch-related reports referenced by the authors are on file with the Billings Curation Center.

\section{References Cited}

Aaberg, Stephen A., William P. Eckerle, and Kenneth P. Cannon

1999 Cree Crossing (24PH3396): The Cultural and Paleoenvironmental Record of a Mid-Holocene to Historic Ford of the Milk River in Northcentral Montana. Submitted to Montana Department of Transportation, Helena, Project No. ER 243-1(np)6. Copies available from Montana State Historic Preservation Office.

Aaberg, Stephen A., Rebecca R. Hanna, Chris Crofutt, Jayme Green, and Marc Vischer

2006 Miles City Field Office Resource Management Plan (RMP) and Environmental Impact Statement (EIS): Class I Overview of Paleontological \& Cultural Resources in Eastern Montana Volume I. Report on file with Bureau of Land Management, Miles City Field Office, Miles City, Montana. 
Alix, Claire, P. Gregory Hare, Thomas D. Andrews, and Glen MacKay

2012 A Thousand Years of Lost Hunting Arrows: Wood Analysis of Ice Patch Remains in Northwestern Canada. Arctic 65(Special Issue):95-117.

Anderson, Douglas D.

1984 Prehistory of North Alaska. In Arctic, edited by David, Damas, pp. 80-93. Handbook of North American Indians, Vol. 5, William C. Sturtevant, general editor, Smithsonian Institution, Washington, D.C.

Anderson, Richard

2014 High Tetons Surrender Clues about Prehistoric Residents. Jackson Hole News \& Guide. Electronic document, http://www.jhnewsandguide.com/news/ environmental/high-tetons-surrender-clues-aboutprehistoric-residents/article_f2ba9672-b097-501ea046-c74d8a099d24.html, accessed December 5, 2015.

Andrews, Thomas D., Glen MacKay, and Leon Andrew

2012 Archaeological Investigations of Alpine Ice Patches in the Selwyn Mountains, Northwest Territories, Canada. Arctic 65(Special Issue):1-21.

Baker, C.J.

2016 Melting Alpine Snow Exposes Ancient History to Area Archaeologists. Powell Tribune 5 January. Electronic document, http://www.powelltribune.com/news/ item/14392-melting-alpine-snow-exposes-ancienthistory-to-area-archaeologists, accessed January 6 , 2016.

Bamforth, Douglas B., and Peter Bleed

1997 Technology, Flaked Stone Technology, and Risk. In Rediscovering Darwin: Evolutionary Theory and Archeological Explanation, edited by C. Michael Barton and Geoffrey A. Clark, pp. 109-139. Archeological Papers of the American Anthropological Association, 7. American Anthropological Association, Arlington, Virginia.

Beckhoff, Klaus

1965 Eignung und Verwendung Einheimischer Holzarten für Prähistorischer Pfeilschäfte. Die Kunde N. F. 16:5161

Benedict, James B., Robert J. Benedict, Craig M. Lee, and Dennis Staley

2008 Spruce Trees from a Melting Ice Patch: Evidence for the Beginning of Neoglaciation in Rocky Mountain National Park, Colorado. Holocene 18:1067-1076.

Bleed, Peter

1986 The Optimal Design of Hunting Weapons: Maintainability or Reliability. American Antiquity 51:737-747.

Boas, Franz

1899 Property Marks of Alaskan Eskimo. American Anthropologist 1:601-13.

Brunswig, Robert $\mathrm{H}$.

2014 Risks and Benefits of Global Warming and the Loss of Mountain Glaciers and Ice Patches to Archeological, Paleoclimate, and Paleoecology Resources. Ecological Questions 20:99-108.

Bunn, Andrew. G., Brian C. Peters, Jeremy S. Littell, and Lisa J. Graumlich

2004 Biophysical Controls on the Spatial Distribution of Deadwood above Treeline in the Southern Sierra Nevada, USA. Poster presented at the Mountain Climate Sciences Symposium, Lake Tahoe, Nevada.

Callanan, Martin

2013 Melting Snow Patches Reveal Neolithic Archery. Antiquity 87:728-745.
Carlquist, Sherwin

1988 Comparative Wood Anatomy. Springer-Verlag, Berlin.

Carrara, Paul E.

2011 Deglaciation and Postglacial Treeline Fluctuation in the Northern San Juan Mountains, Colorado. Professional Paper 1782. U.S. Geological Survey, Reston, Virginia.

Carrara, Paul E., and John P. McGeehin

2015 Evidence of a Higher Late-Holocene Treeline along the Continental Divide in Central Colorado. Holocene 25:1-9

Cundy, Barry J.

1989 Formal Variation in Australian Spear and Spearthrower Technology. BAR International Series 546, Oxford.

Dixon, E. James, Craig M. Lee, William F. Manley, Ruth Ann Warden, and William D. Harrison

2007 The Frozen Past of Wrangell-St. Elias National Park and Preserve. Alaska Park Science: Scientific Studies on Global Warming 6:24-29.

Dixon, E. James, William F. Manley, and Craig M. Lee

2005 The Emerging Archeology of Glaciers and Ice Patches: Examples from Alaska's Wrangell-St. Elias National Park and Preserve. American Antiquity 70:129-143

Dove, Carla J., Gregory Hare, and Marcy Heacker

2005 Identification of Ancient Feather Fragments Found in Melting Alpine Ice Patches in Southern Yukon. Arctic 58:38-43.

Eakin, Daniel H.

2005 Evidence for Shoshonean Bighorn Sheep Trapping and Early Historic Occupation in the $A b$ saroka Mountains of Northwest Wyoming. 29th Annual Report, Vol. 29. Article 36. University of Wyoming National Park Service Research Center. Electronic document, http://repository.uwyo.edu/uwnpsrc reports/vol29/iss1/36/, accessed October 24, 2016.

Equinox

2013 Journal of Glacial Archaeology. Electronic document, equinoxpub.com/journals/index.php/JGA, accessed July 23, 2015.

Fountain, Andrew

2009 Glaciers of the American West. Electronic document, http://glaciers.research.pdx.edu/glaciersmontana, accessed October 15, 2011.

Frison, George C.

1991 Prehistoric Hunters of the High Plains, 2nd ed. Academic Press, San Diego, California.

2004 Survival by Hunting: Prehistoric Human Predators and Animal Prey. University of California Press, Berkeley.

Frison, George C., Charles A. Reher, and Daniel N. Walker 1990 Prehistoric Mountain Sheep Hunting in the Central Rocky Mountains of North America. In Hunters of the Recent Past, edited by Leslie B. Davis and Brian O.K. Reeves, pp. 208-240. Unwin Hyman, London.

Glacier Cultural Resource Management Group (GCRMG)

2015 Ice Patch Research Worldwide. Ice Patch Archaeology and Paleoecology Project, Glacier National Park. Electronic document, www.glaciericepatch.org/ ResearchWorld/index.php, accessed August 1, 2015.

Greiser, Sally T., T. Weber Greiser, and Susan M. Vetter

1985 Middle Prehistoric Period Adaptations and Paleoenvironment in the Northwestern Plains: The Sun River Site. American Antiquity 50:849-877. 
Gruhn, Ruth

1961 The Archaeology of Wilson Butte Cave, SouthCentral Idaho. Occasional Papers of the Idaho State College Museum No. 6. Idaho State College, Pocatello.

Hafner, Albert

2012 Archaeological Discoveries on Schnidejoch and at Other Ice Sites in the European Alps. Arctic 65(Special Issue):189-202.

Hare, P. Gregory Hare, Sheila Greer, Ruth Gotthardt, Richard Farnell, Vandy Bowyer, Charles Schweger, and Diane Strand

2004 Ethnographic and Archaeological Investigations of Alpine Ice Patches in Southwest Yukon, Canada. Arctic 57:260-272.

Hare, P. Gregory, Christian D. Thomas, Timothy N. Topper, and Ruth M. Gotthardt

2012 The Archaeology of Yukon Ice Patches: New Artifacts, Observations, and Insights. Arctic 65(Special Issue):118-135.

Hayes, Virgil

1994 Turning Weights. Atlatl 7(3):1-4

Helwig, Kate, Valery Monahan, and Jenifer Poulin

2008 The Identification of Hafting Adhesive on a Slotted Antler Point from a Southwest Yukon Ice Patch. American Antiquity 73:279-288.

Helwig, Kate, Valery Monahan, Jennifer Poulin, and Thomas D. Andrews

2014 Ancient Projectile Weapons from Ice Patches in Northwestern Canada: Identification of Resin and Compound Resin-Ochre Hafting Adhesives. Journal of Archaeological Science 41:655-665.

Hoadley, R. Bruce

1990 Identifying Wood: Accurate Results with Simple Tools. Taunton Press, Newtown, Connecticut.

Husted, Wilfred M., and Robert Edgar

2002 The Archeology of Mummy Cave, Wyoming:

An Introduction to Shoshonean Prehistory. National Park Service Midwest Archeological Center and Southeast Archeological Center Special Report No. 4, Technical Reports Series No. 9, Lincoln, Nebraska.

InsideWood

2004 InsideWood Database. Electronic document, http:// insidewood.lib.ncsu.edu/search, accessed October, 2013.

Interagency Bison Management Plan (IBMP)

20142014 IBMP Adaptive Management Plan. Electronic document, http://www/ibmp.info/Library/ Adaptivemgmt/2014_IBMP_AdaptiveMgmtPlan_ reformatted.pdf, accessed August 16, 2015.

Kelly, Robert L., Todd A. Surovell, Bryan N. Shuman, and Geoffrey M. Smith

2013 A Continuous Climatic Impact on Holocene Human Population in the Rocky Mountains. Proceedings of the National Academy of Sciences. 110(2):443-447.

Kolb, Scott

2015 Melting Ice Patches Reveal Artifacts. Cody Enterprise. Electronic document, http://www.codyenterprise.com/news/local/article_78a38568-992f11e5-b733-6f8a5b71603f.html, accessed December $12,2015$.

Kornfeld, Marcel, George C. Frison, and Mary Lou Larson 2010 Prehistoric Hunter-Gatherers of the High Plains and Rockies. Left Coast Press, Walnut Creek, California.
Lee, Craig M.

2009 Reconnaissance for Ice Patch Archaeology, Yellowstone National Park: Results of the 2008 Field Season. Prepared for National Park Service, Yellowstone National Park, Mammoth Hot Springs, Wyoming. Report on file with Yellowstone National Park, Mammoth Hot Springs, Wyoming.

2010 Global Warming Reveals Wooden Artefact Frozen over 10,000 Years Ago in the Rocky Mountains. Antiquity 84(325) Online Project Gallery. Electronic document, http://antiquity.ac.uk/projgall/lee325/, accessed February 18, 2016.

2012 Withering Snow and Ice in the Mid-Latitudes: A New Archaeological and Paleobiological Record for the Rocky Mountain Region. Arctic 65(Special Issue):165177.

2013 Final Report of Ice Patch Investigations (20062011) on the Custer and Gallatin National Forests, Montana, and the Shoshone National Forest, Wyoming. Prepared for Custer and Gallatin National Forests, Bozeman and Billings, Montana and Shoshone National Forest, Cody, Wyoming. Report on file with Custer National Forest, Billings, Montana.

2014a Archeological Survey of Perennial Ice Patches on Table Mountain, Yellowstone National Park and the Trident Plateau, Yellowstone National Park and Bridger-Teton National Forest: Results of the 2013 Field Season. Prepared for National Park Service, Yellowstone National Park, Mammoth Hot Springs, Wyoming and Bridger-Teton National Forest, Jackson, Wyoming. Report on file with Yellowstone National Park, Mammoth Hot Springs, Wyoming.

2014b Melting Snow and Ice at the Crossroads of Culture and Climate Change, Phase 1: Ranking Greater Yellowstone Area Snow and Ice Resources with Archaeological and Paleobiological Potential. Prepared for Greater Yellowstone Coordinating Committee, Bozeman, Montana by Montana State University. Report on file with Custer National Forest, Billings, Montana.

Lee, Craig M., and James B. Benedict

2011 Pursuing Archaeology on Ice in the Conterminous United States. Paper presented at the 10th Biennial Rocky Mountain Anthropological Conference, Missoula.

2012 Ice Bison, Frozen Forests and the Search for Archaeology in Colorado Front Range Ice Patches. Colorado Archaeology 78:41-46.

Lee, Craig M., James B. Benedict, and Jennie B. Lee

2006 Ice-Patches and Remnant Glaciers: Paleontological Discoveries and Archeological Possibilities in the Colorado High Country. Southwestern Lore 72:26-43.

Lee, Craig M., Robert L. Kelly, Rachel Reckin, Ira Matt, and Pei-Lin Yu

2014 Ice Patch Archaeology in Western North America. SAA Archaeological Record 14(2):15-19.

Lee, Craig M., Robert L. Kelly, Kathryn Puseman, Rachel Reckin, Ira Matt, and Pei-Lin Yu

2015 Ice Cores from Ice Patches: A Novel Paleoclimate Proxy for the Rocky Mountain Region. Paper presented at the 12th Biennial Rocky Mountain Anthropological Conference, Steamboat Springs, Colorado.

Lee, Craig M., and Halcyon LaPoint

2015 Ice Patch Archaeology in the Greater Yellowstone. Yellowstone Science 23(1):72-73. 
Lee, Craig M., Michael Neeley, Mark D. Mitchell, Marcel Kornfeld, and Crae O'Connor

2016 Microcores and Microliths in Northwestern Plains and Rocky Mountain Front Lithic Assemblages. Plains Anthropologist 61:136-158.

Lewis, William V.

1939 Snow-Patch Erosion in Iceland. Geographical Journal 94(2):153-161.

McConnell, Bill, and Craig M. Lee

2013 Just the Tip: Replication and Use of a 10,400Year-Old Cody-Age Foreshaft. Bulletin of Primitive Technology 46:25-26.

Mitchell, Mark D.

2012 High-Altitude Archaeology in the Uncompahgre Wilderness: Archaeological Investigations During 2010 at the Uncompahgre Cirque Site, Hinsdale County, Colorado. Paleocultural Research Group (PCRG). Submitted to History Colorado State Historical Fund and the U.S. Forest Service, Grand Mesa, Uncomphagre, and Gunnison National Forests, Challenge Cost Share Agreement 09-CS-11020400-047. Research Contribution No. 87. Report on file with Paleocultural Research Group, Broomfield, Colorado.

Morgan, Christopher, Ashley Losey, and Lukas Trout

2014 Late-Holocene Paleoclimate and Treeline Fluctuation in Wyoming's Wind River Range, USA. Holocene 24:209-219.

Nabokov, Peter, and Lawrence Loendorf

2004 Restoring a Presence: American Indians and Yellowstone National Park. University of Oklahoma Press, Norman.

Panshin, Alexis J., and Carl de Zeeuw

1980 Textbook of Wood Technology. McGraw-Hill, New York.

Peck, Trevor

2011 Light from Ancient Campfires: Archaeological Evidence for Native Lifeways on the Northern Plains. Athabasca University Press, Edmonton, Alberta, Canada.

Perkins, William R.

1992 The Weighted Atlatl and Dart: A Deceptively Complicated Mechanical System. Archaeology in Montana 33:65-77.

Peterson, Marcia

2015 Alpine and Ice Patch Archaeology in the CaribouTarghee National Forest and Grand Teton National Park. Program \& Abstracts: Rocky Mountain Anthropological Conference. Steamboat Springs, Colorado.

Reckin, Rachel

2013 Ice Patch Archaeology in Global Perspective: Archaeological Discoveries from Alpine Ice Patches Worldwide and Their Relationship with Paleoclimates. Journal of World Prehistory 26:323-385.

Reimer, Paula J., Mike G. L. Baillie, Edouard Bard, Alex Bayliss, J. Warren Beck, Paul G. Blackwell, Christopher Bronk Ramsey, Caitlin E. Buck, George S. Burr, R. Lawrence Edwards, Michael Friedrich, Pieter M. Grootes, Thomas P. Guilderson, Irka Hajdas, Timothy J. Heaton, Alan G. Hogg, Konrad A. Hughen, Klaus Felix Kaiser, Bernd Kromer, F. Gerry McCormac, Sturt W. Manning, Ron W. Reimer, David A. Richards, John R. Southon, Sahra Talamo, Chris S. M. Turney, Johannes van der Plicht, and Constanze E. Weyhenmeyer

2009 IntCal09 and Marine09 Radiocarbon Age Calibration Curves, 0-50,000 Years cal BP. Radiocarbon 51(4):1111-1150.
Reynolds, Georgeanne Lewis

1989 Ownership Marks and Social Affinity in Northwest Alaska during Late Prehistoric Times. Arctic Anthropology 26:88-107.

Ryd, Yngve

2014 Wild Reindeer and Saami Hunting with Bow and Arrow. Journal of Glacial Archaeology 1:11-24.

Sahagun, Louis

2015 Ancient Artifacts Yield a Modern Dilemma: What Can Be Collected Legally? Los Angeles Times. Electronic document, http://www.latimes.com/ science/la-me-artifacts-20150913-story.html, accessed September 14, 2015.

Scheiber, Lauara L., and María Nieves Zedeño (editors)

2015 Engineering Mountain Landscapes: An Anthropology of Social Investment. University of Utah Press, Salt Lake City.

Schuh, Dwight, G. Fred Asbell, Dave Holt, and M. R. James 1997 Bowhunting Equipment and Skills. Creative Publishing International, Chanhassen, Minnesota.

Sgouros, Rebecca A., and Matthew A. Stirn

2015 An Ice Patch Artifact and Paleobiological Specimen from the Teton Mountains, Wyoming, USA. Journal of Glacial Archaeology 2:3-24.

Shuman, Bryan

2012 Recent Wyoming Temperature Trends, Their Drivers, and Impacts in a 14,000-year Context. Climatic Change 112:429-447.

Todd, Lawrence

2015 A Record of Overwhelming Complexity: High Elevation Archaeology in Northwestern Wyoming. Plains Anthropologist (Memoir 43) 60(236):67-86.

Tolley, Arthur Robert, and Jack Barnes

1979 Reinventing the Atlatl. Journal of the Steward Anthropological Society 10:161-180.

VanderHoek, Richard

1998 The Atlatl and Dart. Unpublished Master's thesis, Department of Anthropology, University of Illinois, Urbana-Champaign.

VanderHoek, Richard, E. James Dixon, Nicholas L. Jarman, and Randolph M. Tedor

2012 Ice Patch Archaeology in Alaska: 2000-10. Arctic 65(Special Issue):153-164.

Vivian, Brian C., and Doug Mitchell

2005 An Archaeological Inventory on the Eastern Edge of the Gallatin Range, Yellowstone National Park, Wyoming: Final Report. Lifeways of Canada Limited for Branch of Cultural Resources, Yellowstone National Park. Report on file with Yellowstone National Park, Wyoming.

Vlcek, David

2015 High Elevation Archaeological Research in the Northern Wind River Range. Program \& Abstracts: Rocky Mountain Anthropological Conference. Steamboat Springs, Colorado.

Weathermon, Rick L.

2011 Late Archaic Hunter-Gatherer Perishable Technologies in the Black Hills: An Investigation of the Crystal Cave Location and its Culturally Modified Wood. Unpublished Ph.D. dissertation, University of Wyoming, Department of Anthropology, Laramie.

Wettlaufer, Boyd N.

1955 The Mortlach Site in the Besant Valley of Central Saskatchewan. Saskatchewan Department of Natural Resources, Anthropological Series No. 1. Regina 
Whittaker, John

2010 Weapon Trials: The Atlatl and Experiments in Hunting Technology. In Designing Experimental Research in Archaeology: Examining Technology through Production and Use, edited by Jeffrey R. Ferguson, pp. 195-224. University Press of Colorado, Boulder.

Wilson, Michael C., John Visser, and Martin P. R. Magne 2011 Microblade Cores from the Northwestern Plains at High River, Alberta, Canada. Plains Anthropologist 56:23-36.

Wormington, H. Marie, and Richard G. Forbis

1965 An Introduction to the Archaeology of Alberta, Canada. Proceedings No. 2. Denver Museum of Natural History, Denver, Colorado.

\section{Notes}

1. An erratum printed in Southwestern Lore 2012 78(2):32-33 provides the version of Table 2 that should have appeared in Lee and Benedict (2012).

2. Early on in the course of this research, Lukas offered a blind second opinion on some of the artifacts collected in 2006 and 2007. Lee did this seeking concordance regarding the identifications. Lukas's observations supported those of Puseman and vice versa.

Submitted April 25, 2016; Revised September 22, 2016; Accepted September 25, 2016 